MÁRIA PISOŇOVÁ

Comenius University

in Bratislava, Slovakia

\title{
THE ASPECTS OF TEACHING AND MANAGEMENT ETHICS
}

ABSTRACT. Pisoňová Mária, The Aspects of Teaching and Management Ethics [Etyka: aspekty nauczania i zarządzania]. Studia Edukacyjne nr 34, 2015, Poznań 2015, pp. 315-323. Adam Mickiewicz University Press. ISBN 978-83-232-2896-7. ISSN 1233-6688. DOI: 10.14746/se.2015. 34.19

The study deals with the development of students' critical thinking, which is influenced by specific methods to reach the education values (axiologization) in the school practice. In addition, it is very important to combine the management and teaching of ethics.

Key words: management ethics, teaching ethics, axiologization, headmaster, teacher, student, critical thinking, morality, erudition, application, methods, dilemma situations

\section{Ethical profile of headmaster in human relationship formation}

In school practice is not usually to talk about the management ethics. Many people think that it is problem of management area. It is the truth? If we use the basic definition of "management ethics" we must conclude that the headmaster's main target is his social behaviour which reflects the generally accepted norms of the community in the school. With other words, the head of the school means the critical and normative reflection. In the school practise it is manifested by 2 ways:

1. By giving the basic normative orientation to the school employees.

2. By giving the steps of self-reflection, self-control and self-regulation of own behaviour. 
The object of management ethics are questions of law and responsible using of power in relationship between headmaster and the employees. The most important is to evaluate the pedagogues fairly, to care about their health and safety, to ensure their civil liberties and rights, etc. Anzenbacher (1994), J.H. Donnely, J. Gipson, J.M. Ivancevich (1995) in Majtán, 2003 tried to define manager's ethic profile. By it the headmaster should follow three groups of principles:

The principles of the behaviour to his own, their basic idea is the positive self-acceptation as a human being. The principles are: self-knowing, selfesteem, self-confidence and self-awareness, self-control and self-criticism.

The principles of behaviour to other people, they contain the main principles of effective communication with other people. They are based on metaprinciple of communication which is esteem to the person as a human being with rights. This group of principles underlines tolerance as a non-violent way of communication, confidentiality, ability to listen to the people, empathy, etc. ${ }^{1}$ assigns the importance to the third group of principles which deal with pure moral profile of manager. She called them ethical-professional. They should care about headmaster's expertise and professionalism. In practice the headmaster shows his responsibility and reliability, discretion, decisiveness, flexibility, ability to motivate and encourage creativity, precision and punctuality, indifference, purposefulness, perseverance, diligence, etc.

Table 1

Expresses the importance of management ethics proper understanding as a sub-system of leading. The name of the table is Management ethics as a sub-system.

\begin{tabular}{|c|c|c|}
\hline Management ethics & Sub-system & Content \\
\hline Morality & Character ethics & Moral ability \\
\hline Erudition & Work ability ethics & $\begin{array}{l}\text { External presentation of } \\
\text { headmaster }\end{array}$ \\
\hline Application & Profession ethics & $\begin{array}{l}\text { Application of morality and } \\
\text { erudition in school leading } \\
\text { practice }\end{array}$ \\
\hline
\end{tabular}

Source: J. Bláha, Z. Dytr, Manažérska etika, Praha 2003, p. 155.

This scheme indicates the importance and connection of sub-systems and their components. It draws attention to the importance of complexity in decision-making and implementation of changes which lead to innovation.

Management ethics is based on three pillars which have been mentioned before. They are: morality, erudition and application. These supplement and

1 A. Remišová, Podnikatel'ská etika v praxi - cesta k úspechu, Bratislava 1999. 
cooperate with each other. The morality area covers the basic moral principles, roles and social norms which should be adhered in the workplace (and not only in the workplace). The erudition area draws attention to specific conditions, the formation of strategic school goals and especially for all life learning pedagogue staff. The application area deals with the practice of everyday requirements and application of management ethics in all organizations and thus school.

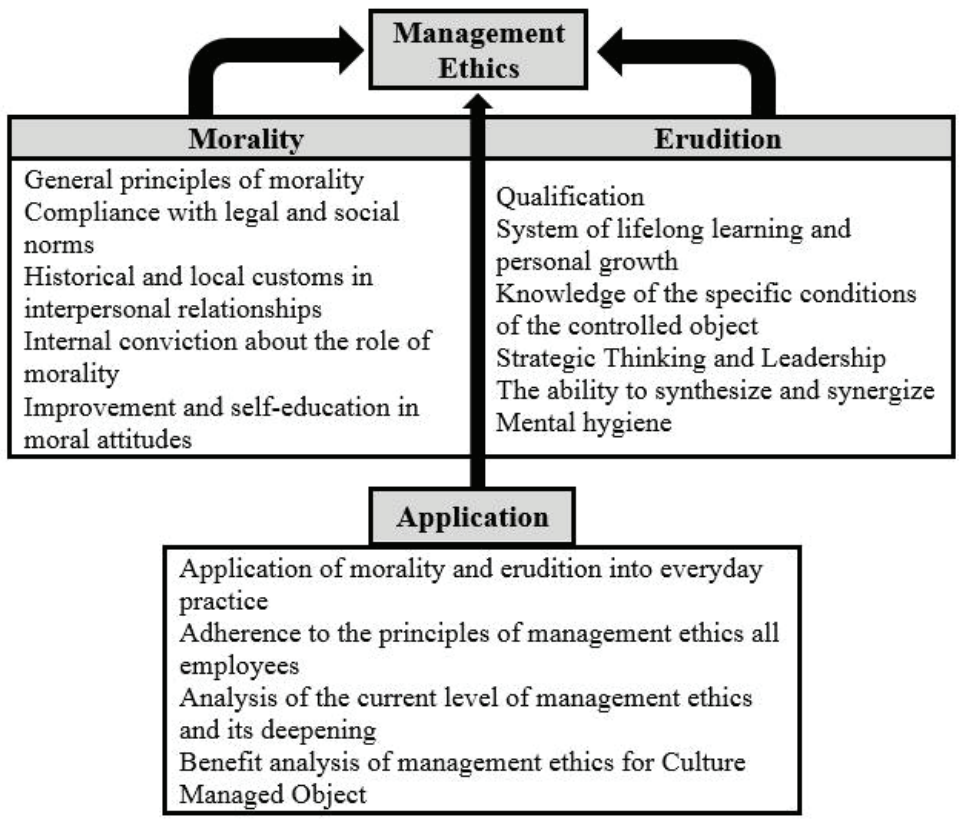

Fig. 1. Aspects of management ethics

(Source: J. Bláha, Z. Dytr, Manažérska etika, 1. vyd., Praha 2003, p. 155)

\section{Normative aspects of teaching ethics}

Leading Slovak university pedagogue prof. PhDr. et PaedDr. Martin Žilínek, CSc. Deals with given topic and he concisely characterizes the base of teaching profession morality in his monograph: Ethos and moral identity formation of personality. Based on the assumption that the headmaster is also a teacher we must ask what is management ethics apart from teaching? The answer is very simple. There are no principal differences in makingdecision. The difference is just target group and the associated choice of communication. The above explanation corresponds to the following expres- 
sion: "teaching ethics can be considered as a specific manifestation of the general status of morality in terms of the teacher's professional activities."2

\section{The teacher in the process of axiologization - values education}

The basic stimulus to develop ethical values is identification what is goodness and what is evil. ${ }^{3}$ According to him, important is the assessment of the behaviour moral aspects, statements, steps. G.I. Kohberg identified six stages of moral development within three levels:

1. The pre-conventional morality - level of anomie in axiologization, it is child's inability to evaluate something on the level of negotiated conventions. It is the inability to decide. This level is typical for children under 9 years, some adolescents and adult criminals. This includes the stages of:

- Obedience due to avoid punishment,

- Seeking reward (praise, recognition).

2. Conventional morality, respectively heteronomy in axiology. Heteronomy valuation is determined by external authority. The person assumes valuation from other people of culture, traditions, habit. The second level is typical for adolescents and adults. This includes the stages of:

- Orientation on social recognition,

- Orientation on law and order.

3. Post-conventional morality is the highest level - autonomy. M. Zelina ${ }^{4}$ describes autonomy as an autonomy valuation, the valuation based on interiorization of external stimulus and own internal experiences, valuations and ideas. It is the third level which the minority of adults reaches it when they are elder that 20. For this stadium is characteristic:

- Orientation on legal social deal (to respect individual rights)

- Orientation on universal ethical principles (evaluation criteria is conscience which deals with own valuation system. ${ }^{5}$

Development of critical thinking and moral development intensifies gradually. It is an axiology process from anomie through heteronomy to autonomy. Nobody can skip any phase or stage of development. The rate of development is not individual, as well as the highest development level. This means that someone could not reach the third level (the level of autonomy) as well as the level of heteronomy. The evaluation is intellectually very

2 M. Žilínek, Étos a utváranie mravnej identity osobnosti, Bratislava 1997, p. 196.

${ }^{3}$ M. Zelina, Metóda: Žalujem - obhajujem - súdim (ŽOS), Rodina a škola, 1996, 46, 7, p. 5.

${ }^{4}$ M. Zelina, Stratégie a metódy rozvoja osobnosti diet'atáa, Bratislava 1996.

${ }^{5}$ G.I. Kohberg in: M. Zelina, Metóda: Žalujem - obhajujem - súdim. 
difficult. It enables to distinguish important phenomenon from unimportant, good from evil. Inseparably valuation belongs to values and it deals with their appreciation. ${ }^{6} \mathrm{M}$. Zelina7 explains the term axiologization. "Axiologization means value education - education to values." M. Zelinová says that the base is to give a stimulus to children. After that children can think about the values, choose specific values freely, make free decisions. ${ }^{8}$ A. Gogová says that the concept of "value" is a term which was interesting for philosophers and pedagogues because the topic of values is connected with the human being. ${ }^{9}$ The term value is the object of psychology, phisolophy, ethics, aesthetics, sociologist, etc interests and studies. From given reason the term is not identical within mentioned sciences. ${ }^{10} \mathrm{~A}$. Gogová defines the value of the psychological point of view as follows: "In psychology the value is understood as everything what is important for an individual. This importance has to be emotional and rational and it regulates our behaviour."11 R.B. Perry concludes that the value means to be the object of interests and inclination. ${ }^{12}$ According to V. Božík ${ }^{13}$, the person is constantly learning how to search, find, determinate, valuate, appreciate, respect use and form new values which nobody knows and thinks. Zelinová M. ${ }^{14}$ notes that the Society look for the new ways how to educate people and the embodiment of full and meaningful human being in the world. In connection with this trend we talk about megatrends which imply merging the values and objectives (individualism, the fight between people, Emphasis on advantages) and also those that arise. These include a feeling of human solidarity, humanism, valuing life, interpersonal relationships, focus on survival, authenticity, trust in human goodness, etc. A. Gogová expresses that there is a kind of key values such as health, education, altruism, family and profession which are generally valid in society. It often happens that person recognizes the key value but it does not prefer in his personal life. ${ }^{15}$ The reality and the value cannot be connected because we could lose our sense of existence. Beauty, goodness and truth are the ideals that express the human desire for perfection. These ideas

${ }^{6}$ J. Slavík in: Z. Kolář, A. Vališová, Analýza vyučování, Praha 2009.

${ }^{7}$ M. Zelina, Metóda: Žalujem - obhajujem - súdim, p. 161.

8 M. Zelinová, Hry na rozvoj hodnotiaceho myslenia, Rodina a škola, 1998, 46, 5; Druhy a spôsoby hodnotiaceho myslenia, Rodina a škola, 1998, 46, 6.

${ }^{9}$ A. Gogová in: A. Gogová, Š. Kročková, G. Pintes, Žiak-sloboda-výchova, Nitra 2004.

${ }^{10}$ M. Verešová, Rozvoj osobnosti žiaka, Nitra 2007, p. 73.

11 A. Gogová in: A. Gogová, Š. Kročková, G. Pintes, Žiak-sloboda-výchova, p. 71.

12 R.B. Perry, S. Kučerová, Úvod do pedagogické antropologie a axiologie, Brno 1990.

${ }_{13}$ V. Božík, Hodnotenie a hodnoty, Nitra 2004, p. 65.

14 M. Zelinová, Výchova človeka pre nové milénium. Teória a prax tvorivo-humanistickej výchovy, Prešov 2004.

${ }^{15}$ A. Gogová in: A. Gogová, Š. Kročková, G. Pintes, Žiak-sloboda-výchova. 
give a sense of human existence and make people constantly overcome himself. ${ }^{16}$ It often happens that a person does not appreciate and aware the most important and valuable values (V. Božík). L. Mihalik ${ }^{17}$ speaks about the importance of building the value system of students and teach them critically distinguish values from pa-value: "Relationship to values is relationship to human being as a highest value. Because of this the axiological education is an essential part of human teaching and education." Zelinová M.18 builds on the theory of C.R. Rogers. The child gradually begins to adopt the values from his or her parents and from other adults. He or she gives up own scheme of valuation which later follows, gradually loses self-confidence. The author names this consequence as "modern alienation of the human". M. Zelina ${ }^{19}$ describes the state of human by words: "The place of valuation is usually located outside." Because the human being is irrelevant to their needs and preferences he or she condemns themselves and is not authentic. The most important is to restore the contact with ourselves to develop the critical thinking. Ideally, individual's valuation system is result of its critical thinking. This means that the resource assessment is in the individual who started to make own decisions, thus becoming an integral being, a single person:

People have become more receptive to own experiential experience, have a positive general direction of organism values. The positive direction is based on tending to the improvement and development of the individuals themselves and other people in society.

\section{Methods based on dilemma situations}

Dilemma situations are more complex problem which involves the consideration of the various alternatives. ${ }^{20}$ says the following dilemma situations that students assessed

Students and many people argue that having a dog at home is immoral, people do not care about the dog, dog makes environment dirty ... second group of people says that having a dog at home is one of the most human and the best thing in the world. How is it? Consider this. Find as many arguments for and against (...).

16 V. Spousta, Vybrané problémy axiologické a estetické výchovy v tabulkách a schématech, Brno 1995, p. 86.

${ }^{17}$ L. Mihálik, Humanistická orientácia základnej školy, Bratislava 1996, p. 75.

18 M. Zelinová, Výchova človeka pre nové milénium.

${ }^{19}$ M. Zelina, Stratégie a metódy, p. 162.

${ }^{20}$ M. Zelinová, Výchova človeka pre nové milénium, p. 130. 
Research of G.A. Kohlberg confirmed that students who participate in regular discussions of moral dilemmas begin to formulate their views at a higher stage of development. In this context it is necessary to underline three methods that belong to the group-based methods dilemma situation:

1. Constructive discussion method is the first of methods based on dilemma situation. The constructive discussion is suitable method how to resolve the interpersonal problems by compromising. M. Zelina ${ }^{21}$ recommends the implementation of this method to define the time and space for argument, define the nature of the problem. The problem shouldn't be solved in agitation. In the case that we do not agree with the opponent we can use accepting rejection (I accept you as a person but do not agree with your ideas). The students have to learn how to offer and accept the compromises. Conclusions should be formulated jointly and clearly in the form of oral or written agreements. This method should be applied while dealing with currently existing situation, conflicts between students so that they learn together effectively how to communicate and solve interpersonal conflicts assertively. Students should learn that everyone can have their own opinion and view of the situation. We also should note the importance of compromise behaviour for their future life.

2. The solution method of moral dilemmas is the second method based on the dilemma situation. The base is to discuss with ethical topics. This is a teacher's non-directive organized group discussion which is based on conflicting microstory. The story may be fictitious or from the lives of students. M. Zelina ${ }^{22}$ describes a method of moral dilemmas as follows. The teacher will present the story first, taking advantage of the video. Then students recap the story. Students have to become the key figures and solve the problem. Change in perspective is also effective when a student has to review the situation from the perspective of different characters. The teacher should prepare questions for the development of critical thinking of students associated with the story. The discussion ends by summarizing the reasons for and against. Students should also present the changes of ideas on the issue with the appropriate explanation. With this method it is very important to create a favourable receiving atmosphere that students do not have to be afraid to express their opinion. We can resolve dilemma situation by various methods. Students can make their statements by oral or writing way within group discussion. The role play as a modelling situation is non-traditional approach.

\footnotetext{
${ }^{21}$ M. Zelina, Stratégie a metódy.

22 Ibidem.
} 
3. The method taking somebody to court - advocating - judging is the third method based on the dilemma situation. In practice we can use this method as a model of the court proceeding. M. Zelina ${ }^{23}$ does not recommend this method for implementation in specific students' offenses in the classroom in order to protect them from the public assessment. M. Verešová ${ }^{24}$ recommends that the teacher and participants evaluate the behaviour of involved, process, formal aspect of speech, persuasive behaviour and other aspects. In practice, sometimes happen that this method is transformed into staging method where students play a role of a judge, defendant and advocate convincingly.

\section{BIBLIOGRAPHY}

Beňo M., Učitel'om - humanistom, Eko-konzult, Bratislava 2003.

Bláha J., Dytr Z., Manažérska etika, 1. vyd., Management Press, Praha 2003.

Boroš J., Motivácia a emocionalita človeka, Odkaz, Bratislava 1995.

Božík V., Hodnotenie a hodnoty, UKF v Nitre, Nitra 2004.

Božík V., O hodnotách a l'ud'och, UKF v Nitre, Nitra 2006.

Capponi V., Novák T., Sám sobě psychologem, Grada, Praha-Nitra 2006.

Eyre L., Eyre R., Jak naučit deti hodnotám, Portál, Praha 2007.

Gogová A., Kročková Š., Pintes G., Žiak-sloboda-výchova, UKF v Nitre, Nitra 2004.

Holúbek J., Axiologizácia v škole a rodine, Rodina a škola, 1996, 44, 7.

Jablonský T., Kolibová D., Matúšová A., The place of school and education in knowledge-based society development, [in:] Sciences of education serving the quality of human life, Verbum, Ružomberok 2010.

Kolář Z., Vališová A., Analýza vyučování, Grada, Praha 2009.

Kolláriková Z. a kol., Rozvoj kritického myslenia na základnej škole, ŠPÚ v Bratislave, Bratislava 1997.

Kosová B., Humanizačné premeny výchovy a vzdelávania alebo ako d’alej na 1. stupni základnej školy, Univerzita Mateja Bela, PF, Banská Bystrica 1995.

Kučerová S., Úvod do pedagogické antropologie a axiologie, Masarykova Univerzita PF, Brno 1990.

Lencz L., Pedagogika etickej výchovy. Výchova k prosociálnosti, Metodické centrum v Bratislave, Bratislava 1998.

Lomnický I., Aktuálny pohl'ad na etickú výchovu v súčasnosti - výchova hodnotami so zameraním na umeleckú tvorbu, [in:] Formácia dobrého človeka, ed. J. Michalov, UKF v Nitre FF, Nitra 2006.

Majtán M. a kol., Manažment, SPRINT, Bratislava 2003.

Matúšková R., Etická výchova na 1. stupni ZŠ, Naša škola, 2008-2009, 46, 7-8.

Mihálik L., Humanistická orientácia základnej školy, Štátny pedagogický ústav v Bratislave, Bratislava 1996.

23 Ibidem.

${ }^{24}$ M. Verešová, Rozvoj osobnosti žiaka, Nitra 2007, p. 73. 
Perry R.B., Kučerová S., Úvod do pedagogické antropologie a axiologie, Masarykova Univerzita PF, Brno 1990.

Pisoňová M. a kol., Školský manažment pre študijné odbory učitel'stva a prípravu vedúcich pedagogických zamestnancov, Univerzita Komenského, Bratislava 2014.

Remišová A., Podnikatel'ská etika v praxi - cesta k úspechu, Epos, Bratislava 1999.

Rogers C.R., Ako byt́ sám sebou, IRIS, Bratislava 1995.

Rogers C.R., Freiberg H.J., Sloboda učit' sa, Persona, Modra 1998.

Rogge J.U., Výchova dětí krok za krokem, Portál, Praha 2007.

Sedláčková D., Rozvoj zdravého sebevědomí žáka, Grada, Praha 2009.

Sollárová E., Aplikácie prístupu zameraného na človeka (PCA) vo vzt́ahoch, Ikar, Bratislava 2005.

Sollárová E. kol., Sociálna psychológia, Fakulta sociálnych vied UKF v Nitre, Nitra 2002.

Spousta V., Vybrané problémy axiologické a estetické výchovy v tabulkách a schématech, Masarykova univerzita v Brně, Brno 1995.

Spousta V., Etické, estetické a noetické hodnoty v soudobé orientaci výchovy, Výchova a vychovávatel', 1995-1996, 40, 3-4.

Verešová M., Rozvoj osobnosti žiaka, UKF v Nitre, Nitra 2007.

Vymětal J., Rezková V., Rogersovský prístup k dospělým a dětem, Portál, Praha 2001.

Zelina M., Stratégie a metódy rozvoja osobnosti dietáatá, IRIS, Bratislava 1996.

Zelina M., Metóda: Žalujem - obhajujem - súdim (ŽOS), Rodina a škola, 1998, 46, 7.

Zelina M., Morálny rozvoj dietáata a axiologizácia, Rodina a škola, 1998, 46, 8.

Zelinová M., Výchova k hodnotám, Rodina a škola, 1998, 46, 2.

Zelinová M., Východiská pre metódy rozvíjania hodnotiaceho myslenia, Rodina a škola, 1998, 46,4 .

Zelinová M., Hry na rozvoj hodnotiaceho myslenia, Rodina a škola, 1998, 46, 5.

Zelinová M., Druhy a spôsoby hodnotiaceho myslenia, Rodina a škola, 1998, 46, 6.

Zelinová M., Výchova človeka pre nové milénium. Teória a prax tvorivo-humanistickej výchovy, Rokus, Prešov 2004.

Zelinová M., Hry pro rozvoj emocí a komunikace. Koncepce a model toořivě-humanistické výchovy, Portál, Praha 2007.

Žilínek M., Étos a utváranie mravnej identity osobnosti, Iris, Bratislava 1997. 